\title{
Gene flow from herbicide resistant transgenic soybean to conventional soybean and wild soybean
}

\author{
Hye Jin Kim ${ }^{1,2}$, Do Young Kim', Ye Seul Moon ${ }^{1}$, In Soon Pack${ }^{1}$, Kee Woong Park ${ }^{2}$, Young Soo Chung ${ }^{3}$, \\ Young Joong Kim${ }^{4}$, Kyong-Hee $\mathrm{Nam}^{5}$ and Chang-Gi Kim ${ }^{1 *}$ (])
}

\begin{abstract}
Gene flow from transgenic crops to conventional cultivars or wild relatives is a major environmental and economic concern in many countries. South Korea is one of the major importer of transgenic crops for food and feed, although commercial cultivation of transgenic crops is not yet allowed in this country. This study evaluated gene flow from the herbicide glyphosate- and glufosinate-resistant transgenic soybean (Glycine max) to five non-transgenic soybean cultivars and three accessions of wild soybean (Glycine soja). Field trials were conducted over 2 years, and gene flow was monitored up to $10 \mathrm{~m}$ distance from the pollen source. The results indicated that the detectable rate of gene flow from transgenic to conventional soybeans varied between 0 and $0.049 \%$ in both 2014 and 2015 field trials, while no hybrids were detected among wild soybean progenies. The highest rate of gene flow was found in the progenies of the Bert cultivar, which exhibited the longest period of flowering synchronization between the pollen donor and the recipient. In addition, overall gene flow rates declined with increased distance from the transgenic soybean plot. Gene flow was observed up to $3 \mathrm{~m}$ and $8 \mathrm{~m}$ from the transgenic soybean plot in 2014 and 2015, respectively. Our results may be useful for developing measures to prevent gene flow from transgenic soybean.
\end{abstract}

Keywords: Biosafety, Gene flow, Glycine max, Glycine soja, Herbicide resistance, Hybridization

\section{Introduction}

Commercially available transgenic soybeans are mostly resistant to glyphosate or glufosinate. Glyphosate is a broad spectrum non-selective herbicide that inhibits the synthesis of aromatic amino acids in plants. The expression of the EPSPS enzyme from Agrobacterium strain CP4 (CP4 EPSPS) confers glyphosate resistance in plants [1]. Glufosinate is also a broad spectrum non-selective herbicide that inhibits glutamine synthetase. The expression of the bar gene from Streptomyces hygroscopicus can confer glufosinate resistance in plants [2].

\footnotetext{
*Correspondence: parkkw@cnu.ac.kr; cgkim@kribb.re.kr

${ }^{1}$ Bio-Evaluation Center, Korea Research Institute of Bioscience \&

Biotechnology, Cheongju 28116, Republic of Korea

2 Department of Crop Science, Chungnam National University,

Daejeon 34143, Republic of Korea

Full list of author information is available at the end of the article
}

In 2017, worldwide transgenic soybean (Glycine max (L.) Merr.) cultivation areas reached 94.1 million ha [3]. Although cultivation of transgenic crops is not yet allowed in South Korea, large amounts of transgenic crops are imported for food and feed; in 2018, South Korea imported 1.0 million tons of transgenic soybeans [4]. In addition, various transgenic soybeans have been developed and their performance has been tested in experimental fields in South Korea [5-9].

Both cultivated soybean and wild soybean (Glycine soja Siebold and Zucc.) belong to the subgenus Soja, and the latter is considered a progenitor of the former [10]. Soybean originated from China and the center of diversity extends to Korea, Japan, and the Far East region of Russia [11]. Although soybean self-fertilizes and its pollination occurs before the flower opens [12], interspecific hybridization between soybean and wild soybean has been reported [13]. 
Crop-to-crop gene flow is an important economic concern. The gene flow from transgenic to non-transgenic conventional soybean has been studied mainly for determining isolated distance and gene flow rate. The studies conducted in Brazil, China, and Japan reported that gene flow rate is less than $1.0 \%$, and gene flow can occur up to $10 \mathrm{~m}$ from the transgenic pollen source [14-16].

Gene flow from transgenic to wild soybean is a major environmental concern for countries, including Korea, Japan, China, and far eastern Russia, which are centers of origin and diversity of soybean [17]. Gene flow from transgenic soybean to wild soybean was investigated in Japan and was reported that the maximum rate of natural hybridization was also less than $1.0 \%[18,19]$.

Recently, Lee et al. [20] reported a field study on gene flow from transgenic vitamin A fortified soybean to nontransgenic soybean in South Korea. However, this study investigated the gene flow only up to $2.7 \mathrm{~m}$ from the pollen source. Studies regarding gene flow from transgenic soybean to wild soybean under field conditions have not been reported in South Korea. The present study was conducted to determine gene flow rates from glyphosate- and glufosinate-resistant transgenic soybeans to five commercial soybean cultivars and three accessions of wild soybeans in South Korea.

\section{Materials and methods Plant materials}

A transgenic line (Bert-4-3) of soybean (G. max) was developed from the cultivar 'Bert' (a non-transgenic control), to consist of 5-enolpyruvylshikimate-3-phosphate synthase (EPSPS) gene from the Agrobacterium tumefaciens strain CP4. Its expression is under the control of the cauliflower mosaic virus $35 \mathrm{~S}$ promoter and nos terminator. The transgenic line has the bar gene for glufosinate resistance as a selection marker. Therefore, this transgenic soybean is resistant to both glyphosate and glufosinate. Seeds of this transgenic soybean and Bert were provided by one of the authors (YS Chung).

We used wild soybeans, a non-transgenic control line, and commercial soybean cultivars as pollen recipients. Three accessions (IT236798, IT236816, and IT241179) of wild soybean (G. soja) seeds were obtained from the National Agrobiodiversity Center, South Korea. Seeds of four commercial soybean cultivars; 'Daepung, 'Daewon', 'Hwangkeum', and 'Taekwang', were provided by Chungcheongbuk-do Agricultural Research and Extension Services, South Korea.

The cultivars Daewon and Daepung are classified as Group VI maturity and Hwangkeum and Taekwang are classified as Group V maturity [21]. These four cultivars have determinate growth habits [22]. The cultivar Bert is classified as Group I maturity in the U.S. and exhibits an indeterminate growth habit [23].

\section{Field experiments}

Field experiments were conducted over 2 years in an experimental field at the Korea Research Institute of Bioscience and Biotechnology (KRIBB), Cheongju, Chungcheongbuk-do, Korea $\left(36^{\circ} 43^{\prime} \mathrm{N}, 127^{\circ} 26^{\prime} \mathrm{E}\right.$; elevation, $35 \mathrm{~m})$.

In May 2014, we established a $10 \times 10 \mathrm{~m}$ plot of transgenic soybean with wild soybean and five $2 \times 10 \mathrm{~m}$ nontransgenic soybean plots with 10 rows mulched with black plastic films (Fig. 1a). On 17 April 2014, seeds of three wild soybean accessions (IT236798, IT236816, and IT241179) were sown in a greenhouse. Twenty seedlings per accession were transplanted after 4 weeks of growth on 16 May 2014. Seeds of transgenic and non-transgenic soybeans were sown on 26 May 2014 in a greenhouse. On 10 June 2014, 140 transgenic soybean seedlings and 40 seedlings for each non-transgenic soybean cultivar were transplanted into the plots with a $50-\mathrm{cm}$ spacing.

Ten plants were randomly selected and the flowering period was monitored for each soybean and wild soybean line. The days that the first open flower appeared and the last flower disappeared were recorded for each plant. The days leading to flowering were calculated as the period from sowing up to the day the first open flower appeared. Flowering date was considered as the date when $40-50 \%$ of the monitored plants had begun to flower. Days leading to flowering were calculated; the seeds of Bert and wild soybean IT236816 were harvested in September, and Daepung, Daewon, Hwankeum, Taekwang, IT236798, and IT241179 were harvested in October. Approval for the field trial was obtained from the Rural Development Administration (Approval number: 2014-012).

In May 2015, we established a $10 \times 10 \mathrm{~m}$ transgenic soybean plot with 10 rows, five $2 \times 10 \mathrm{~m}$ non-transgenic soybean plots with 10 rows, and a $7 \times 10.5 \mathrm{~m}$ transgenic soybean-wild soybean plot with seven rows (Fig. 1b); each row was mulched with black plastic films. Seeds of transgenic, non-transgenic, and wild soybean were sown in a greenhouse on 27 May 2015. On 10 June 2015, 200 transgenic soybean seedlings were transplanted in the central plot and 40 non-transgenic soybean seedlings per cultivar were transplanted on the right section. On the left side from the central plot, transgenic soybean (110 seedlings) and wild soybean (10 seedlings per accession) seedlings were transplanted on the same date. Both soybean and wild soybean seedlings were planted at $50-\mathrm{cm}$ spacing; flowering periods were monitored as described above. Seeds of Bert and wild soybeans were harvested in September and Daepung, Daewon, Hwangkeum, and Taekwang were harvested in October. Insecticides were 
a
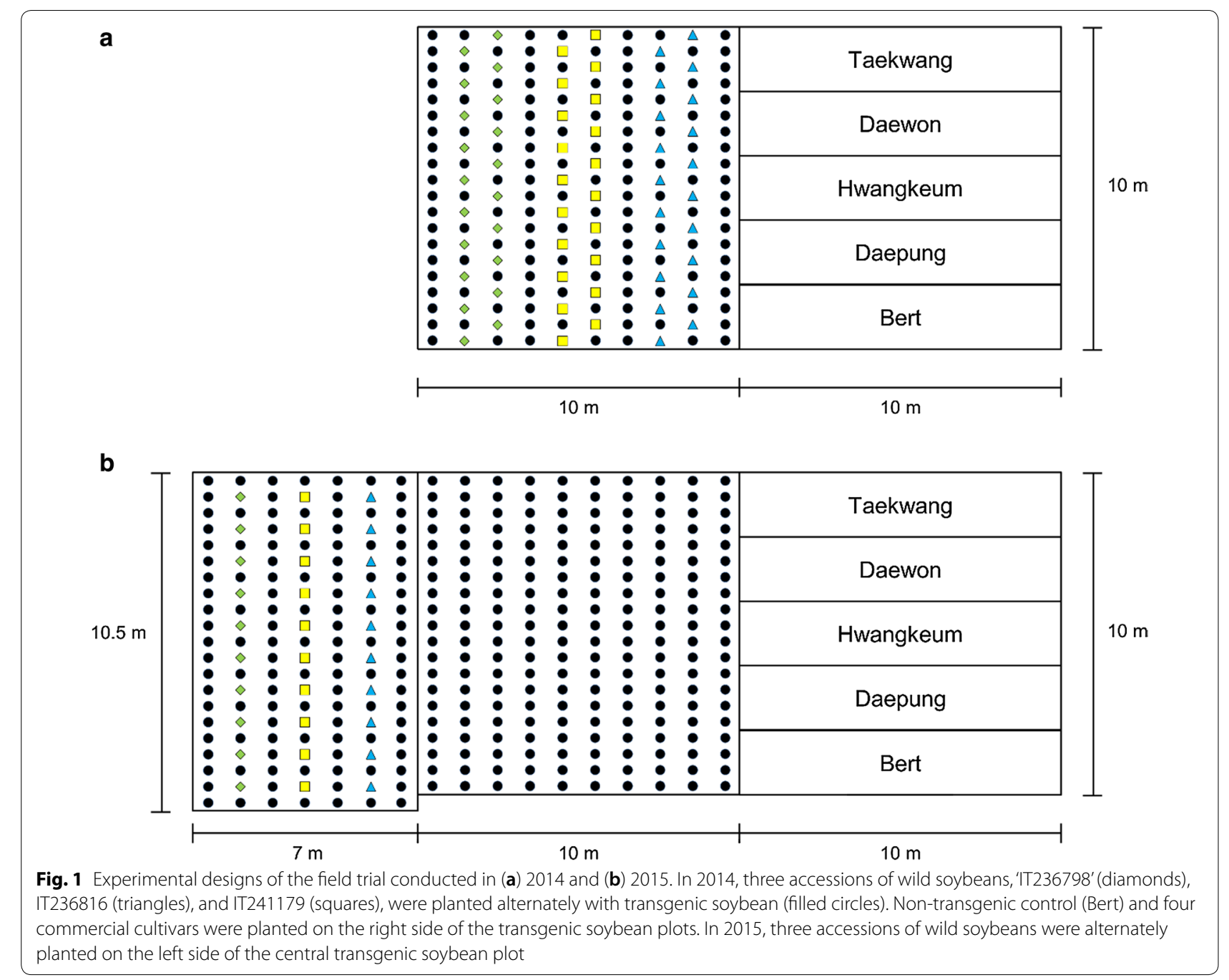

not used in both trials. Approval for the field trial was obtained from the Rural Development Administration (Approval number: 2015-003).

\section{Hybrid detection}

Resistance to glufosinate was tested to screen hybrid seedlings. Seed number was tallied using an automatic seed counter (Aidex Co., Japan) and 200 seeds of nontransgenic soybean cultivars and 300 seeds of wild soybeans were placed in a plastic tray $(52 \times 36 \times 9 \mathrm{~cm})$ containing commercial potting soil in a greenhouse. We measured seed germination rates to estimate the number of evaluated progenies. Germination rates (\%) were determined by counting the number of germinated seedlings from non-transgenic soybean seeds (10 replications) and wild soybean seeds (20 replications). Glufosinate (Basta; Bayer) was applied at a concentration of $3 \mathrm{ml} / \mathrm{L}$ using a garden sprayer when non-transgenic soybean plants reached the three-leaf stage and wild soybean plants reached the four-leaf-stage.

Leaf samples of seedlings that survived after glufosinate application were collected and the presence of transgene was confirmed using PCR. Genomic DNA was extracted using a FastDNA kit (MP bio., USA). A pair of primers; Lectin F (5'-ATCCGACGATGGATTTCTTG-3) and Lectin R (5'-GGCGGCATTATAGGTAACGA-3), were designed to amplify the 217-bp lectin gene. EPSPS F (5'GATCTCCCACCGGTCCTTCA-3) and EPSPS R (5'CGCCATCGATGATCCAGGTG-3) were designed to amplify EPSPS (158 bp). All primers were synthesized by Bioneer (Daejeon, Korea).

PCR was conducted to amplify lectin, with a final volume of $50 \mu \mathrm{L}$ that contained: $2 \mu \mathrm{L}$ of gDNA, $25 \mu \mathrm{L}$ of AccuPower $^{\circledR}$ PCR Master Mix (Bioneer, Korea), $19 \mu \mathrm{L}$ of distilled water (Bioneer, Korea), and $2 \mu \mathrm{L}$ of 10 pmol for each primer. Conditions for amplification included: an initial denaturation at $95{ }^{\circ} \mathrm{C}$ for $3 \mathrm{~min}, 35$ cycles of 
denaturation at $95{ }^{\circ} \mathrm{C}$ for $30 \mathrm{~s}$, annealing at $59{ }^{\circ} \mathrm{C}$ for $30 \mathrm{~s}$, and extension at $72{ }^{\circ} \mathrm{C}$ for $30 \mathrm{~s}$; followed by a final extension at $72{ }^{\circ} \mathrm{C}$ for $5 \mathrm{~min}$. PCR was conducted for the amplification of EPSPS with a final volume of $50 \mu \mathrm{L}$ that contained: $1 \mu \mathrm{L}$ of gDNA, $25 \mu \mathrm{L}$ of AccuPower ${ }^{\circledR}$ PCR Master Mix (Bioneer, Korea), $19 \mu \mathrm{L}$ of distilled water (Bioneer, Korea), and $2.5 \mu \mathrm{L}$ of $10 \mathrm{pmol}$ for each primer. Conditions for amplification included: an initial denaturation at $94{ }^{\circ} \mathrm{C}$ for $3 \mathrm{~min}, 35$ cycles of denaturation at $94{ }^{\circ} \mathrm{C}$ for $30 \mathrm{~s}$, annealing at $60^{\circ} \mathrm{C}$ for $30 \mathrm{~s}$, and extension at $72{ }^{\circ} \mathrm{C}$ for $50 \mathrm{~s}$; followed by a final extension at $72{ }^{\circ} \mathrm{C}$ for $5 \mathrm{~min}$. Transgenic soybean was used as the positive control and distilled water was used as the negative control. The gene flow rates were calculated as the percentages of the number of hybrids per number of evaluated progenies.

\section{Results}

In 2014, transgenic soybean plants flowered for 54 days between 27 June and 20 August (Table 1). The synchronization times of flowering Bert, was the longest (54 days). Daepung, Daewon, Hwangkeum, and Taekwang began to flower 5, 5, 11, and 19 days later than transgenic soybean, respectively. The flowering periods of these four cultivars partially overlapped with those of transgenic soybean. Seeds of wild soybeans were sown 5 weeks earlier than those of transgenic soybeans, resulting in two accessions of wild soybeans; IT236798 and IT241179, flowering 19 and 10 days earlier than transgenic soybeans, respectively. However, IT236816 flowered 17 days later than transgenic soybean and flowering periods of this accession and transgenic soybean partially overlapped.

In 2015, transgenic soybean plants flowered for 52 days between 20 June and 11 August (Table 1). Bert flowered
1 day earlier than transgenic soybean and ceased to flower on 26 August. Daepung, Daewon, Hwangkeum, and Taekwang began to flower 13, 18, 19, and 23 days later than transgenic soybean, respectively. Flowering periods of transgenic and wild soybeans did not overlap at all in 2015 when the seeds of wild soybeans were sown on the same date (27 May) as transgenic soybean. IT236798, IT236816, and IT241179 began to flower 58, 60 , and 60 days later than transgenic soybeans and their flowering periods were 30,21 , and 21 days, respectively.

In 2014, 51,055 progenies of non-transgenic soybeans were assessed to identify hybrids (Table 2). Germination rates of Bert, Daepung, Daewon, Hwangkeum, and Taekwang in 2014 were 93.7, 89.4, 75.4, 90.3, and $88.7 \%$, respectively. The overall gene flow rate of Bert was $0.037 \%$; greater than the rates of Daepung $(0.009 \%)$, Hwangkeum (0.007\%), and Taekwang $(0.012 \%)$, while hybrids were not found in Daewon. Gene flow was observed within $3 \mathrm{~m}$ from the transgenic soybean plot. The greatest gene flow rate was observed for Taekwang at a $2 \mathrm{~m}$ distance $(0.145 \%)$ from the transgenic soybean plot. Overall, eight hybrids were found out of 51,055 progenies in 2014 (gene flow rate: $0.016 \%$ ). PCR analysis showed the presence of 158-bp EPSPS gene fragment in samples.

In 2015, 31,796 progenies of non-transgenic soybeans were assessed to locate hybrids (Table 3). Germination rates of Bert, Daepung, Daewon, Hwangkeum, and Taekwang were $91.2,79.9,53.8,49.7$, and $56.9 \%$, respectively. The overall gene flow rates of Bert were $0.049 \%$; greater than those of Daepung (0.009\%). Hybrids were not found for Daewon, Hwangkeum, and Taekwang. Hybrid progenies were observed up to $8 \mathrm{~m}$ from the transgenic soybean plot. The highest gene flow rate was observed for Bert at $1 \mathrm{~m}$ distance $(0.120 \%)$ from the transgenic

Table 1 Flowering of transgenic soybean, five cultivars of conventional soybeans, and three accessions of wild soybeans

\begin{tabular}{|c|c|c|c|c|c|c|}
\hline \multirow{2}{*}{$\begin{array}{l}\text { Soybean/wild } \\
\text { soybean }\end{array}$} & \multicolumn{3}{|l|}{2014} & \multicolumn{3}{|l|}{2015} \\
\hline & $\begin{array}{l}\text { First flowering } \\
\text { date (month- } \\
\text { date) }\end{array}$ & $\begin{array}{l}\text { Final flowering } \\
\text { date (month- } \\
\text { date) }\end{array}$ & $\begin{array}{l}\text { Flowering } \\
\text { synchronization } \\
\text { times (days) }\end{array}$ & $\begin{array}{l}\text { First flowering } \\
\text { date (month- } \\
\text { date) }\end{array}$ & $\begin{array}{l}\text { Final flowering } \\
\text { date (month- } \\
\text { date) }\end{array}$ & $\begin{array}{l}\text { Flowering } \\
\text { synchronization } \\
\text { times (days) }\end{array}$ \\
\hline Transgenic & $6-27$ & $8-20$ & - & $6-20$ & $8-11$ & - \\
\hline Bert & $6-26$ & $9-1$ & 54 & $6-19$ & $8-26$ & 52 \\
\hline Daepung & $7-2$ & $8-20$ & 49 & $7-3$ & $8-26$ & 39 \\
\hline Daewon & $7-2$ & $9-4$ & 49 & $7-8$ & $9-9$ & 34 \\
\hline Hwangkeum & $7-8$ & $8-20$ & 43 & $7-9$ & $8-26$ & 33 \\
\hline Taekwang & $7-16$ & $8-20$ & 35 & $7-13$ & $8-26$ & 29 \\
\hline IT236796 & $6-8$ & $9-12$ & 54 & $8-17$ & $9-16$ & 0 \\
\hline IT236816 & $7-14$ & $9-12$ & 37 & $8-19$ & $9-9$ & 0 \\
\hline IT241179 & $6-17$ & $9-12$ & 54 & $8-19$ & $9-9$ & 0 \\
\hline
\end{tabular}

In 2014, transgenic and conventional soybeans were sown on 26 May, and wild soybeans were sown on 17 April. In 2015 , both soybeans and wild soybeans were sown on 27 May 
Table 2 Rates of gene flow from transgenic to five cultivars of non-transgenic soybean at a range of distance in 2014

\begin{tabular}{|c|c|c|c|c|c|c|}
\hline $\begin{array}{l}\text { Distance } \\
\text { from transgenic plot } \\
\text { (m) }\end{array}$ & Bert & Daepung & Daewon & Hwangkeum & Taekwang & Pooled data \\
\hline 1 & 2/1504 (0.133) & $0 / 1088$ & $0 / 549$ & 1/1594 (0.063) & 0/979 & $3 / 5714(0.053)$ \\
\hline 2 & 2/1522 (0.131) & 0/1090 & $0 / 235$ & $0 / 1347$ & $1 / 690(0.145)$ & $3 / 4884(0.061)$ \\
\hline 3 & 1/1255 (0.080) & 1/1295 (0.077) & $0 / 311$ & 0/1791 & $0 / 941$ & 2/5593 (0.036) \\
\hline 4 & $0 / 1613$ & $0 / 1237$ & $0 / 502$ & $0 / 1583$ & 0/881 & $0 / 5816$ \\
\hline 5 & 0/1298 & $0 / 1164$ & $0 / 404$ & $0 / 1479$ & 0/1006 & $0 / 5351$ \\
\hline 6 & $0 / 1485$ & 0/1189 & $0 / 367$ & $0 / 1236$ & 0/892 & $0 / 5169$ \\
\hline 7 & $0 / 1548$ & $0 / 673$ & $0 / 80$ & $0 / 1514$ & $0 / 736$ & $0 / 4551$ \\
\hline 8 & 0/1596 & 0/1195 & $0 / 406$ & 0/1292 & $0 / 806$ & 0/5295 \\
\hline 9 & 0/699 & $0 / 1049$ & $0 / 489$ & $0 / 1284$ & $0 / 505$ & $0 / 4026$ \\
\hline 10 & 0/1060 & 0/883 & $0 / 424$ & $0 / 1312$ & 0/977 & $0 / 4656$ \\
\hline Total & $5 / 13,580(0.037)$ & $1 / 10,863(0.009)$ & $0 / 3767$ & $1 / 14,432(0.007)$ & $1 / 8413(0.012)$ & $8 / 51,055(0.016)$ \\
\hline
\end{tabular}

Values are the number of PCR-positive progenies/number of evaluated progenies. Numbers in parentheses are the gene flow rates (\%)

Table 3 Rates of gene flow from transgenic to five cultivars of non-transgenic soybean at a range of distance in 2015

\begin{tabular}{lllllll}
\hline $\begin{array}{l}\text { Distance } \\
\text { from transgenic plot } \\
(\mathbf{m})\end{array}$ & Bert & Daepung & Daewon & Hwangkeum & Taekwang & Pooled data \\
\hline 1 & & & & & & \\
\hline & $2 / 1663(0.120)$ & $0 / 1116$ & $0 / 30$ & $0 / 497$ & $0 / 51$ & $2 / 3357(0.060)$ \\
3 & $1 / 1659(0.060)$ & $1 / 1310(0.076)$ & $0 / 81$ & $0 / 492$ & $0 / 88$ & $2 / 3630(0.055)$ \\
4 & $0 / 1556$ & $0 / 1282$ & $0 / 204$ & $0 / 474$ & $0 / 252$ & $0 / 3768$ \\
5 & $1 / 1531(0.065)$ & $0 / 1183$ & $0 / 82$ & $0 / 573$ & $0 / 187$ & $0 / 3207$ \\
6 & $0 / 1335$ & $0 / 1131$ & $0 / 199$ & $0 / 355$ & $0 / 257$ & $0 / 3429$ \\
7 & $0 / 1265$ & $0 / 1100$ & $0 / 294$ & $0 / 513$ & $0 / 135$ & $1 / 2775(0.036)$ \\
8 & $1 / 1152(0.087)$ & $0 / 889$ & $0 / 123$ & $0 / 476$ & $0 / 247$ & $1 / 2957(0.034)$ \\
9 & $1 / 1036(0.097)$ & $0 / 1064$ & $0 / 122$ & $0 / 488$ & $0 / 178$ & $0 / 3066$ \\
10 & $0 / 964$ & $0 / 1230$ & $0 / 245$ & $0 / 449$ & $0 / 241$ & $0 / 2092$ \\
Total & $0 / 202$ & $0 / 834$ & $0 / 390$ & $0 / 425$ & $0 / 1782$ & $7 / 31,796(0.022)$
\end{tabular}

Values are the number of PCR-positive progenies/number of evaluated progenies. Numbers in parentheses are the gene flow rates (\%)

soybean plot. Overall, seven hybrids were found among 31,796 progenies in 2015 (gene flow rate: $0.022 \%$ ).

The rates of gene flow from transgenic to non-transgenic control Bert obtained from both 2014 and 2015 field trials were pooled (Fig. 2). Overall gene flow rates decreased when the distance from the transgenic soybean plot increased and the highest gene flow rate was estimated as $0.208 \%$ at a $0 \mathrm{~m}$ distance, indicating a negative correlation between gene flow rate and distance.

In total, 152,504 seeds were harvested from wild soybean plants in 2014 (Table 4). Germination rates of IT236798, IT236816, and IT241179 seeds were 40.7, 47.7, and $45.3 \%$, respectively. No hybrids were found among 68,168 progenies of wild soybean that were evaluated. In 2015 , the number of harvested seeds and the germination rates were lower compared to the seeds collected in 2014. In total, 44,091 seeds were harvested and the germination rates of IT236798, IT236816, and IT241179 seeds were $23.6,14.1$, and $18.0 \%$, respectively (Table 4). In 2015, no hybrids were found among 7452 progenies that were evaluated.

\section{Discussion}

In both 2014 and 2015, the overall rate of gene flow from the herbicide resistant transgenic soybean to the nontransgenic conventional soybean was $0.02 \%$. Among the conventional cultivars, hybrids were not found in Daewon for both years and were not found for Hwangkeum and Taekwang in 2015. This may partially result from the late flowering period of those cultivars compared to 


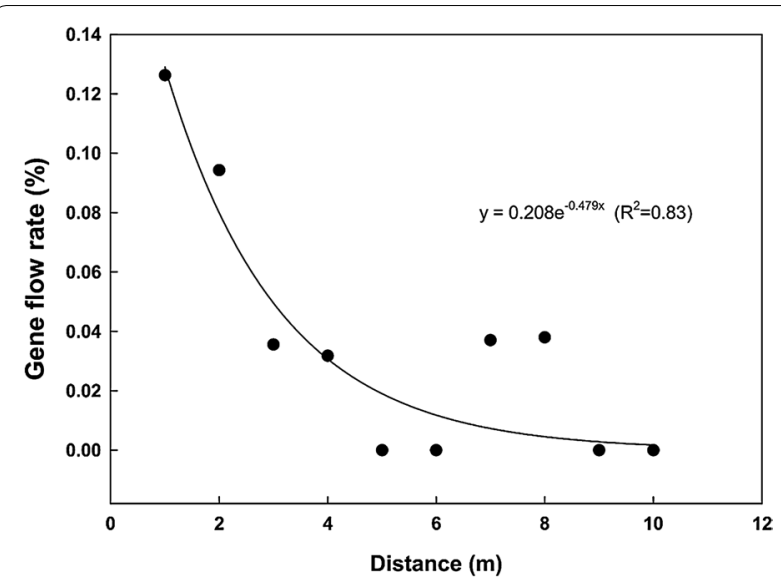

Fig. 2 Rates of gene flow from herbicide resistant transgenic soybean to non-transgenic control (Bert) at various distances from the transgenic soybean plot. Each data point represents the gene flow rate calculated from the pooled data of Bert for 2 years of field tests

transgenic soybean. Bert belongs to Maturity Group I in the US; however, Hwangkeum and Taekwang belong to Maturity Group V (148-155 days to mature), and Daewon and Daepung belong to Maturity Group VI (156-163 days to mature) in Korea [21].

The low number of evaluated progenies, resulting from the low number of harvested seeds and low germination rate, may have also affected the absence of hybrids. Owing to the low gene flow rate of soybean, it can be difficult to find hybrid progenies when an insufficient number of plants is examined. For Daepung, only one hybrid among 10,863 and 11,139 evaluated progenies was found for both years. Hwangkeum and Taekwang also had only one hybrid among 14,432 and 8413 from evaluated progenies in 2014. Therefore, the number of evaluated progenies for Daewon (3767 and 1770 in 2014 and 2015, respectively), and Hwangkeum (4742) and Taekwang (1782) in 2015, may not have been adequate to detect gene flow. This is supported by a 4-year study of gene flow from glyphosate resistant transgenic soybean to conventional soybean by Yoshimura et al. [14]. Their results were affected by the number of evaluated progenies in each year. Gene flow rates $(0.068 \%)$ in 2001 were observable due to the high number of evaluated progenies $(40,904)$ compared to $0 \%$ outcrossing in 2003 (4941 progenies).

Crop-to-crop gene flow has been studied to determine isolation distances from transgenic to conventional crop fields. In the present study, gene flow from transgenic to conventional soybean was observed up to $3 \mathrm{~m}$ in 2014 and $8 \mathrm{~m}$ in 2015. Yoshimura et al. [14] reported that the gene flow occurred up to $7 \mathrm{~m}$ distance from glyphosate resistant transgenic soybean; however, this distance varied yearly. In Brazil, gene flow was found up to $10 \mathrm{~m}$ from glyphosate resistant transgenic soybean to a non-transgenic control variety [15]. Huang et al. [16] observed that gene flow occurred up to $15 \mathrm{~m}$ from glyphosate resistant transgenic soybean to a conventional soybean variety. Therefore, the results of our study fell within the ranges of distances reported by other studies.

The highest gene flow rate found in the present study was $0.14 \%$ at a $2 \mathrm{~m}$ distance from the transgenic soybean plot. When the gene flow rate of the non-transgenic control (Bert) was plotted against distance, the highest rate was estimated as $0.21 \%$. This result is comparable to the result of Yoshimura et al. [14], in which the highest gene flow rate was $0.19 \%$, while Abud et al. [15] and Huang et al. [16] reported $0.73 \%$ and $0.93 \%$ as the highest gene flow rates, respectively.

Wind is not considered a contributing factor for the outcrossing of soybean. Through a wind tunnel experiment, Yoshimura et al. [24] showed that soybean pollen is not dispersed by wind. Outcrossing of soybean is largely caused by insect pollinators; mostly by honey bees, Apis mellifera (Hymenoptera: Apidae) [25-28]. In addition, Gill and O'Neal [29] found that the flower-visiting flies; such as syrphids (Diptera: Syrphidae), were

Table 4 Rates (\%) of gene flow from transgenic soybean to three accessions of wild soybeans in 2014 and 2015

\begin{tabular}{|c|c|c|c|c|c|}
\hline Year & $\begin{array}{l}\text { Wild soybean } \\
\text { accession }\end{array}$ & $\begin{array}{l}\text { Total number of harvested } \\
\text { seeds }\end{array}$ & $\begin{array}{l}\text { Number of evaluated } \\
\text { progenies }\end{array}$ & $\begin{array}{l}\text { Number of progenies } \\
\text { with transgenes }\end{array}$ & $\begin{array}{l}\text { Gene flow } \\
\text { rate (\%) }\end{array}$ \\
\hline \multirow[t]{4}{*}{2014} & IT236798 & 42,852 & 17,126 & 0 & 0 \\
\hline & IT236816 & 57,238 & 27,276 & 0 & 0 \\
\hline & IT241179 & 52,414 & 23,766 & 0 & 0 \\
\hline & Total & 152,504 & 68,168 & 0 & 0 \\
\hline \multirow[t]{4}{*}{2015} & IT236798 & 6045 & 1424 & 0 & 0 \\
\hline & IT236816 & 21,009 & 2964 & 0 & 0 \\
\hline & IT241179 & 17,037 & 3064 & 0 & 0 \\
\hline & Total & 44,091 & 7452 & 0 & 0 \\
\hline
\end{tabular}


among the most abundant pollinators in soybean fields and Milfont et al. [28] reported solitary bees (Hymenoptera: Megachilidae), thrips (Thysanoptera: Thripidae), and lepidopteran species were found near soybean flowers. In the present study, we also observed pollinators during the course of the field trials, including: honey bees, solitary bees, syrphids, thrips, and cabbage white butterfly, Pieris rapae (Lepidoptera: Pieridae) on soybean flowers; however, their activities were not quantified.

Our study did not observe hybrid progenies between transgenic soybean and wild soybean. In our study, the flowering periods of transgenic and wild soybean were synchronized in 2014; however, they were not synchronized in 2015. In addition, poor seed production of the wild soybean accessions in 2015 reduced the number of evaluated progenies. This difference in experimental design and low number of evaluated progenies may have affected the results of our study. Dorokhov et al. [30] also reported that hybrid progenies between glyphosate resistant transgenic soybean and wild soybean were not obtained in their study for two growing seasons. Mizuguti et al. [31] first reported gene flow from transgenic soybean to wild soybean under field conditions. In their following report, 38 progenies were found out of 204,881 evaluating progenies [19]. It was suggested that synchronization of the flowering period between transgenic soybean and wild soybean, the number of insect pollinators, and distance are three important factors that affect gene flow rates from soybean to wild soybean [32].

Introgression of herbicide resistant traits from transgenic soybean into wild soybean may hinder weed management with herbicides [17]. However, Goto et al. [33] suggested that gene flow from imported transgenic soybean to wild soybean populations is unlikely. Spillage of soybean seeds along transportation routes does not frequently occur in Japan and soybean is not a self-sustaining plant in nature. They also indicated that imported soybean and wild soybean should be geographically and temporally overlapped for outcrossing; outcrossing rate between the two species are also very low. In South Korea, transgenic soybean has been mostly imported for oil crushing. The monitoring for the unintended environmental release of transgenic soybean from 2009 to 2018 found only 2 soybean plants near a feed company in 2011, indicating that soybean is not a competitive plant [34].

We detected that the gene flow rate from glyphosate and glufosinate resistant transgenic soybean to five nontransgenic cultivars ranged from 0 to $0.049 \%$, depending on the difference in flowering synchronization times between the pollen donor and recipient, during 2 years of field trials. We also observed that gene flow occurred up to $3 \mathrm{~m}$ and $8 \mathrm{~m}$ from the transgenic soybean plot in 2014 and 2015, respectively. However, no hybrids were found in the progenies of three wild soybean accessions. Our results may be useful for developing measures to prevent gene flow from transgenic soybean.

\section{Acknowledgements \\ Not applicable.}

\section{Authors' contributions}

HJK and CGK analyzed the data and wrote the manuscript; HJK, DYK, YSM, ISP, and YJK performed the experiments; YSC prepared the plant materials; YJK and KHN revised the manuscript; KWP and CGK designed the research. All authors read and approved the final manuscript.

\section{Funding}

This research was supported by Grants from the KRIBB Research Initiative Program and "Cooperative Research Program for Agriculture Science and Technology Development (Project No. PJ01368601)", Rural Development Administration, Republic of Korea.

Availability of data and materials

The datasets used and/or analyzed during the current study are available from the corresponding author on reasonable request.

\section{Competing interests}

The authors declare that they have no competing interests.

\section{Author details}

${ }^{1}$ Bio-Evaluation Center, Korea Research Institute of Bioscience \& Biotechnology, Cheongju 28116, Republic of Korea. ${ }^{2}$ Department of Crop Science, Chungnam National University, Daejeon 34143, Republic of Korea. ${ }^{3}$ Department of Genetic Engineering, Dong-A University, Busan 49315, Republic of Korea. ${ }^{4}$ Division of Restoration Research, National Institute of Ecology, Yeongyang 36531, Republic of Korea. ${ }^{5}$ Division of Ecological Conservation, National Institute of Ecology, Seocheon 33657, Republic of Korea.

Received: 11 July 2019 Accepted: 24 September 2019

Published online: 17 October 2019

\section{References}

1. Padgette SR, Kolacz KH, Delannay X, Re DB, LaVallee BJ, Tinius CN, Rhodes WK, Otero YI, Barry GF, Eichholtz DA, Peschke VM, Nida DL, Taylor NB, Kishore GM (1995) Development, identification, and characterization of a glyphosate-tolerant soybean line. Crop Sci 35:1451-1461

2. Thompson CJ, Rao Movva N, Tizard R, Crameri R, Davies JE, Lauwereys M, Botterman J (1987) Characterization of the herbicide-resistance gene bar from Streptomyces hygroscopicus. EMBO J 6:2519-2523

3. ISAAA (2017) Global status of commercialized biotech/GM crops in 2017: Biotech crop adoption surges as economic benefits accumulate in 22 years. ISAAA Brief No. 53. ISAAA, Ithaca, NY

4. Korea Biosafety Clearing House (2019) Imports of GM food and feed. https://www.biosafety.or.kr/sub/info.do?m=030202\&s=kbch. Accessed 14 Mar 2019

5. Seo JS, Sohn HB, Noh K, Jung C, An JH, Donovan CM, Somers DA, Kim DI, Jeong SC, Kim CG, Kim HM, Lee SH, Choi YD, Moon TW, Kim CH, Cheong JJ (2012) Expression of the Arabidopsis AtMYB44 gene confers drought/ salt-stress tolerance in transgenic soybean. Mol Breed 29:601-608

6. Kim MJ, Kim JK, Kim HJ, Pak JH, Lee JH, Kim DH, Choi HK, Jung HW, Lee JD, Chung YS, Ha SH (2012) Genetic modification of the soybean to enhance the B-carotene content through seed-specific expression. PLoS ONE 7:e48287

7. Nam KH, Kim DY, Pack IS, Park JH, Seo JS, Choi YD, Cheong JJ, Kim CH, Kim CG (2016) Comparative analysis of chemical compositions between nontransgenic soybean seeds and those from plants over-expressing AtJMT, the gene for jasmonic acid carboxyl methyltransferase. Food Chem 196:236-241 
8. Kim HJ, Cho HS, Pak JH, Kwon T, Lee JH, Kim DH, Lee DH, Kim CG, Chung YS (2018) Confirmation of drought tolerance of ectopically expressed AtABF3 gene in soybean. Mol Cell 41:413-422

9. Nam KH, Kim DY, Kim HJ, Pack IS, Kim HJ, Chung YS, Kim SY, Kim CG (2019) Global metabolite profiling based on GC-MS and LC-MS/MS analyses in ABF3-overexpressing soybean with enhanced drought tolerance. Appl Biol Chem 62:15

10. Hymowitz T (1970) On the domestication of the soybean. Econ Bot 24:408-421

11. Andersson MS, de Vicente MC (2010) Gene flow between crops and their wild relatives. The Johns Hopkins University Press, Baltimore

12. Caviness CE (1966) Estimates of natural cross-pollination in Jackson soybeans in Arkansas. Crop Sci 6:211-212

13. Fukuda Y (1933) Cyto-genetical studies on the wild and cultivated Manchurian soy beans (Glycine L.). Jpn J Bot 6:489-506

14. Yoshimura Y, Matsuo K, Yasuda K (2006) Gene flow from GM glyphosatetolerant to conventional soybeans under field conditions in Japan. Environ Biosaf Res 5:169-173

15. Abud S, de Souza PIM, Vianna GR, Leonardecz E, Moreira CT, Faleiro FG, Júnior JN, Monteiro PMFO, Rech EL, Aragão FJL (2007) Gene flow from transgenic to nontransgenic soybean plants in the Cerrado region of Brazil. Genet Mol Res 6:445-452

16. Huang WK, Peng H, Wang GF, Cui JK, Zuh LF, Long HB, Peng DL (2014) Assessment of gene flow from glyphosate-resistant transgenic soybean to conventional soybean in China. Acta Physiol Plant 36:1637-1647

17. Lu BR (2004) Conserving biodiversity of soybean gene pool in the biotechnology era. Plant Species Biol 19:115-125

18. Nakayama Y, Yamaguchi H (2002) Natural hybridization in wild soybean (Glycine max ssp. soja) by pollen flow from cultivated soybean (Glycine max ssp. max) in a designed population. Weed Biol Manag 2:25-30

19. Mizuguti A, Ohigashi K, Yoshimura Y, Kaga A, Kuroda Y, Matsuo K (2010) Hybridization between GM soybean (Glycine max (L.) Merr.) and wild soybean (Glycine soja Sieb. et Zucc.) under field conditions in Japan. Environ Biosaf Res 9:13-23

20. Lee B, Oh SD, Chang A (2018) Influence of gene flow from GM to non-GM soybeans by the size of the pollen donor. Korean J Agric Sci 45:591-600

21. Ha TJ, Lim SG, Shin SH, Choi KJ, Baek IY, Lee SC, Park KY, Shin SO (2009) Maturity grouping of Korean soybean cultivars and character relationships according to the planting date. Korean J Crop Sci 54:104-118

22. Rural Development Administration (2019) Nongsaro-variety information. http://www.nongsaro.go.kr/portal/ps/psz/psza/contentMai n.ps?menuld $=$ PS00112. Accessed 4 Sep 2019

23. Orf JH, Kennedy BW (1992) Registration of 'Bert' soybean. Crop Sci 32:830
24. Yoshimura Y (2011) Wind tunnel and field assessment of pollen dispersal in soybean [Glycine max (L.) Merr.]. J Plant Res 124:109-114

25. Abrams Rl, Edwards CR, Harris T (1978) Yields and cross-pollination of soybeans as affected by honey bees and alfalfa leafcutting bees. Am Bee 118:555-560

26. Erickson EH, Berger GA, Shannon JG, Robins JM (1978) Honey bee pollination increases soybean yields in the Mississippi Delta region of Arkansas and Missouri. J Econ Entomol 71:601-603

27. Chiari WC, de Toledo VAA, Ruvolo-Takasusuki MCC, de Oliveira AJB, Sakaguti ES, Attencia VM, Costa FM, Mitsui MH (2005) Pollination of soybean (Glycine max L. Merril) by honeybees (Apis mellifera L.). Braz Arch Biol Techn 48:31-36

28. Milfont MO, Rocha EEM, Lima AON, Freitas BM (2013) Higher soybean production using honeybee and wild pollinators, a sustainable alternative to pesticides and autopollination. Environ Chem Lett 11:335-341

29. Gill KA, O'Neal ME (2015) Survey of soybean insect pollinators: community identification and sampling method analysis. Environ Entomol 44:488-498

30. Dorokhov D, Ignatov A, Deineko E, Serjapin A, Ala A, Skryabin K (2004) Potential for gene flow from herbicide-resistant GM soybeans to wild soya in the Russian Far East. In: den Nijs HCM, Bartsch D, Sweet J (eds) Introgression from genetically modified plants into wild relatives. CABI Publishing, Wallingford

31. Mizuguti A, Yoshimura Y, Matsuo K (2009) Flowering phenologies and natural hybridization of genetically modified and wild soybeans under field conditions. Weed Biol Manag 9:93-96

32. Mizuguti A (2011) Fundamental study for ecological risk assessment and evaluation of genetically modified crops, especially soybean (Glycine max) and canola (Brassica napus) in Japan. J Weed Sci Technol 56:100-103

33. Goto H, McPherson MA, Comstock BA, Stojšin D, Ohsawa R (2017) Likelihood assessment for gene flow of transgenes from imported genetically modified soybean (Glycine max (L.) Merr.) to wild soybean (Glycine soja Seib. et Zucc.) in Japan as a component of environmental risk assessment. Breed Sci 67:348-356

34. Lee JR, Lim HS, Kim IR, Choi W, Park JH, Jung YJ, Kim DW, Eom SJ, Seol MA, Hwang JE (2018) Study on environmental monitoring and post-managment of LMO. National Institute of Ecology, Seocheon

\section{Publisher's Note}

Springer Nature remains neutral with regard to jurisdictional claims in published maps and institutional affiliations.

\section{Submit your manuscript to a SpringerOpen ${ }^{\circ}$ journal and benefit from:}

- Convenient online submission

- Rigorous peer review

- Open access: articles freely available online

- High visibility within the field

Retaining the copyright to your article

Submit your next manuscript at springeropen.com 